\title{
Public Infrastructure, Private Input Demand, and Economic Performance of the
}

\author{
Greek Industry ${ }^{1}$ \\ E.C. Mamatzakis \\ Queen Mary and Westfield College
}

February, 1999

\begin{abstract}
In this paper we examine the effects of the services provided by public infrastructure on the cost structure, private input demands, and productivity performance of twenty two-digit Greek manufacturing industries. The model of the paper is the dual cost function. Although the effects of public infrastructure varies across different industries our results provide evidence in favour of a productive public infrastructure. In addition, public infrastructure is found to be complement to private capital stock and substitute to labour. Specifically, the cost-saving impact of public infrastructure ranges from 0.02 percent in food manufacturing industry to 0.78 percent in wood and cork. Moreover, empirical evidence is provided in favour of the argument that the productivity growth of the majority of the twenty Greek manufacturing industries has been depressed by the observed shortage in public infrastructure in the eighties.
\end{abstract}

Key words: Dual cost function, productivity growth, infrastructure.

JEL classification: H54, E62, L60.

$1 *$ Comments welcome. I would like to thank Jonathan Haskel for his very useful comments in an earlier version of this paper. Remaining errors are my own. The address for correspondence is: Department of Economics, Queen Mary and Westfield College, Mile End Road, London E1 4NS (e-mail: e.mamatzakis@qmw.ac.uk). 


\section{INTRODUCTION}

In this paper we take advantage of the duality theory between production and cost functions in order to access the productivity effect of public infrastructure on the cost structure of selected Greek industries. Using the dual cost function framework we also estimate factor adjustment effects due to public infrastructure and, hence we comment on whether public infrastructure is complement or substitute to the other inputs of production. In urban and regional studies (see Costa et al (1987)) is taken per-se that public infrastructure is complement to private capital stock. This is known as the 'public capital hypothesis'. One of the aims of the present paper is to seek for empirical evidence of the public capital hypothesis but also to investigate the nature of the relationship between public capital stock and labour.

Our choice to use the dual cost function is also justified by our disaggregated data set. More precisely, our data set consists of two digit Greek manufacturing industries. Berndt (1991) states that cost function are more efficient ways to measure productivity factor bias effects at a disaggregated level, mainly because output can be plausibly assumed to be exogenous within such a framework.

Moreover, the parameter estimates of the translog cost function can be used to examine the contribution of public infrastructure on the productivity growth of each individual two-digit Greek manufacturing industry. Our empirical analysis on the productivity growth is based on the paper of Morrison and Schwartz (1996). More precisely, we modify the primal rate of productivity growth, namely the Solow residual, in order to disentangle and identify the impact of public infrastructure on the productivity growth of the Greek manufacturing industries. Our findings suggest that shortage in public infrastructure is responsible for the observed decline in the productivity growth of most of the two digits Greek-manufacturing industries.

Section 2 outlines our theoretical and empirical framework to access the way that the cost structure of the Greek industrial sector is affected by the provision of public infrastructure. Section 3 and 4 report our data set and empirical results respectively. The present paper ends with a short summary and concluding remarks with some economic policy implications.

\section{AN EMPIRICAL MODEL}

A translog cost function similar to one introduced by Christensen et al (1973) is adopted in the present paper in order to capture the effects of public infrastructure on the cost structure of a number of Greek industrial sectors. More analytically the translog specification is a second-order Taylor's series approximation in logs to an arbitrary cost function augmented for the purposes of our analysis by public infrastructure, which is regarded as a fixed, unpaid factor of production. Nadiri and Mamouneas (1994) treated public infrastructure in a similar way. However the main difference between the present model and their cost function is that they assume homotheticity, while we do not impose such a restriction. More analytically, our translog cost function takes the following form 


$$
\begin{aligned}
& \operatorname{lnC}=\alpha_{0}+\alpha_{\mathrm{L}} \ln \mathrm{P}_{\mathrm{L}}+\alpha_{\mathrm{k}} \ln \mathrm{P}_{\mathrm{K}}+\alpha_{\mathrm{Y}} \ln \mathrm{Y}+\alpha_{\mathrm{G}} \ln \mathrm{G}+\alpha_{\mathrm{T}} \mathrm{T}+\frac{1}{2} \beta_{\mathrm{LL}}\left(\ln \mathrm{P}_{\mathrm{L}}\right)^{2}+\frac{1}{2} \beta_{\mathrm{KK}}\left(\ln \mathrm{P}_{\mathrm{K}}\right)^{2} \\
& +\frac{1}{2} \beta_{\mathrm{GG}}(\operatorname{lnG})^{2}+\frac{1}{2} \beta_{\mathrm{YY}}(\ln \mathrm{Y})^{2}+\frac{1}{2} \beta_{\mathrm{TT}} \mathrm{T}^{2}+\sum_{i=L, j=K} \gamma_{j} \ln P_{i} \ln P_{j}+\sum_{i=L, K} \gamma_{i \mathrm{Y}} \ln P_{i} \ln Y+ \\
& \sum_{i=L, K} \gamma_{i T} \ln P_{i} T+\sum_{i=L, K} \gamma_{i G} \ln P_{i} \ln G+\gamma_{\mathrm{YT}} \ln \mathrm{Y} \mathrm{T}+\gamma_{\mathrm{YG}} \ln \mathrm{Y} \ln \mathrm{G}+\gamma_{\mathrm{GT}} \ln \mathrm{TT}
\end{aligned}
$$

where for symmetry it is assumed that $\gamma_{\mathrm{ij}}=\gamma_{\mathrm{ji}}$, and $\gamma_{\mathrm{iY}}=\gamma_{\mathrm{Yi}}$ for $\mathrm{i}, \mathrm{j}=\mathrm{K}, \mathrm{L}$, and G.

Additionally, in order the translog cost function to be well behaved it should be homogenous of degree 1 in the private purchased inputs of production, L, K. In terms of the notation of equation (1) this assumption implies that

$\alpha_{\mathrm{K}}+\alpha_{\mathrm{L}}=1, \beta_{\mathrm{LL}}+\gamma_{\mathrm{KL}}=0, \gamma_{\mathrm{LK}}+\beta_{\mathrm{KK}}=0, \gamma_{\mathrm{LY}}+\gamma_{\mathrm{KY}}=0, \gamma_{\mathrm{KT}}+\gamma_{\mathrm{LT}}=0$ and $\gamma_{\mathrm{LG}}+\gamma_{\mathrm{KG}}=0$

Notice that equation (1) is non homothetic, $\gamma_{\mathrm{iY}} \neq 0(\forall \mathrm{i}=\mathrm{L}, \mathrm{K})$, thus it allows us to identify scale bias effects.

Further more we can employ Shephard's Lemma to derive the cost minimising cost shares for the private purchased inputs, $\mathrm{L}$ and $\mathrm{K}$, as well as the cost shares for output and infrastructure. More precisely the cost shares under competitive markets for labour and private capital stock are

$$
\begin{aligned}
& \mathrm{L}^{*}=\mathrm{S}_{\mathrm{L}}=\frac{d \ln C}{d \ln P_{L}}=\alpha_{\mathrm{L}}+\gamma_{\mathrm{LT}} \mathrm{T}+\beta_{\mathrm{LL}} \ln \mathrm{P}_{\mathrm{L}}+\gamma_{\mathrm{LK}} \ln \mathrm{P}_{\mathrm{K}}+\gamma_{\mathrm{LY}} \ln \mathrm{Y}+\gamma_{\mathrm{LG}} \operatorname{lnG} \\
& \mathrm{K}^{*}=\mathrm{S}_{\mathrm{K}}=\frac{d \ln C}{d \ln P_{K}}=\alpha_{\mathrm{K}}+\gamma_{\mathrm{KT}} \mathrm{T}+\beta_{\mathrm{KK}} \ln \mathrm{P}_{\mathrm{K}}+\gamma_{\mathrm{LK}} \ln \mathrm{P}_{\mathrm{L}}+\gamma_{\mathrm{KY}} \ln \mathrm{Y}+\gamma_{\mathrm{KG}} \ln \mathrm{G}
\end{aligned}
$$

and the cost shares of output and public infrastructure are

$$
\begin{aligned}
& \mathrm{S}_{\mathrm{Y}}=\frac{d \ln C}{d \ln Y}=\alpha_{\mathrm{Y} 0}+\gamma_{\mathrm{YT}} \mathrm{T}+\sum_{j=L, K} \gamma_{Y} \ln P_{j}+\beta_{\mathrm{YY}} \ln \mathrm{Y}+\gamma_{\mathrm{YG}} \ln \mathrm{G} \\
& \mathrm{S}_{\mathrm{G}}=-\left(\frac{d \ln C}{d \ln G}\right)=-\left(\alpha_{\mathrm{G}}+\gamma_{\mathrm{GT}} \mathrm{T}+\sum_{i=L, K} \gamma_{i G} \ln P_{i}+\beta_{\mathrm{GG}} \ln \mathrm{G}+\beta_{\mathrm{YG}} \ln \mathrm{Y}\right)
\end{aligned}
$$

The homogeneity of degree one in prices of private purchased inputs implies that the shares of private purchased inputs sum to one

$$
\mathrm{S}_{\mathrm{L}}+\mathrm{S}_{\mathrm{K}}=1
$$

Although it is feasible to directly estimate the translog cost function, it is common practice in empirical applications to estimate it jointly with private input demands within a system of equations. This simultaneous estimation is more efficient because it employs more information from a system of equations rather than a single equation 
(see Berndt (1990) for more details). Hence we opt to estimate a system of equations comprised of the total cost function and the private input demands. The specific system of equations would be estimated within a stochastic framework by adding a disturbance term, $\mathrm{u}_{\mathrm{i}}$, to input demands and translog cost function equations. The economic intuition behind this inclusion of random errors is very thoroughly explained by Berndt (1990) who reports that '...firms make random errors in choosing their cost-minimising inputs bundles (pg 247)'. Therefore, a vector of error terms, $\mathrm{u}=\left\{\mathrm{u}_{\mathrm{K}}, \mathrm{u}_{\mathrm{L}}, \mathrm{u}_{\mathrm{TC}}\right\}$, is added in the system of equations of demand for labour and private capital stock, and the total cost function. This vector is normally distributed with the mean vector equals to zero and constant covariance matrix, $\Omega$.

Notice that the private purchased input shares sum up to one, equation (4), for each observation of the sample period over all equations. Hence, the covariance matrix of the disturbance term, $\Omega$, is singular and non diagonal. In our case with two private purchased input demand equations $\left(S_{\mathrm{L}}\right.$ and $\left.\mathrm{S}_{\mathrm{K}}\right)$ in order to overcome the problem of singularity only one of the demands could be jointly estimated with the translog cost function. $^{2}$

Having derived the parameter estimates of equation 1 from the system of equations of translog cost function and private input demands, we can proceed with the estimation the 'productivity effect' of public infrastructure. Moreover, in order to measure the 'productivity effects' of public infrastructure we estimate the elasticity of cost with respect to public capital stock. This elasticity ${ }^{3}$ is given as

$$
\eta_{\mathrm{G}}=\frac{d \ln C}{d \ln G}
$$

In previous empirical research (see for example Morrisson and Schwartz (1994)) public infrastructure was found to be a productive unpaid input, implying a negative sign for $\eta_{\mathrm{G}}$. Therefore, it was argued that investment in public infrastructure saves private costs.

Additionally, to the cost saving effects that may stem out of public infrastructure, industries that benefit from the provision of public infrastructure services could adjust their private purchased inputs demands. These types of effects are mentioned in the relevant literature as 'factor adjustment' effects. A way to measure 'factor adjustment effects' is to estimate the elasticticity of private purchased inputs, in our case labour and private capital stock, with respect to public infrastructure, that is

\footnotetext{
${ }^{2}$ Berndt (1990) suggests as a solution to the singularity problem to arbitrary drop a share equation and then estimate the remaining shares together with the cost function using maximum likelihood (ML) estimation procedure. He showed that maximum likelihood method allows the researcher to get invariant parameter estimates to the choice of which share equation is dropped.

${ }^{3}$ Notice that equation (5) is equivalent to the share of public capital stock on the total cost as given in equation ( $3 b)$.
} 


$$
\eta_{\mathrm{LG}}=\frac{d \ln L}{d \ln G}
$$

and for private capital stock

$$
\eta_{\mathrm{KG}}=\frac{d \ln K}{d \ln G}
$$

More precisely, in the case that $\eta_{\mathrm{iG}}$, where $\mathrm{i}=\mathrm{L}, \mathrm{K}$, is greater, equal or less than zero public infrastructure has enhancing, neutral or saving effect on the ith input. Equivalently a positive sign of the specific elasticity implies complementarity between public infrastructure and the ith input. On the other hand a negative sign or a zero outcome indicates substitutability or neutrality between public infrastructure and the ith input respectively.

\subsection{PRODUCTIVITY GROWTH OF TWENTY GREEK MANUFACTURING INDUSTRIES: A THEORETICAL REPRESENTATION}

Apart from the productivity effect measured by the 'shadow share' of public infrastructure $\left(\eta_{\mathrm{G}}\right)$, which provides a direct mechanism for considering the effect of public infrastructure on productivity of the Greek manufacturing industries, one can estimate a measure of productivity growth and subsequently decompose it into its different components. In what follows, the theoretical methodology proposed by Morrison and Schwartz (1996) is adopted in order to derive estimates of the productivity growth for the Greek manufacturing industries.

The starting point in the productivity growth measurement literature is the famous paper of Solow (1957). In his paper Solow derive a distinction between movements along the production function and shifts in the production function. This distinction gave rise to the famous Solow residual, which is a measure of growth in productivity.

The Solow residual can be written in terms of our notation as follows:

$$
\text { Productivity Growth }=\varepsilon_{\mathrm{YT}}=(\Delta \mathrm{Y} / \mathrm{Y})-\Sigma_{\mathrm{i}} \mathrm{S}_{\mathrm{i}}\left(\Delta \mathrm{X}_{\mathrm{i}} / \mathrm{X}_{\mathrm{i}}\right) \text {, }
$$

where $\mathrm{X}_{\mathrm{i}}$ are the quantities of variable inputs of production ( $\mathrm{L}$ and $\mathrm{K}$ ), and $\mathrm{Y}$ represents the industrial output, $\Delta$ indicates the derivative with respect to time.

Although the above measure offers a way to account for shifts in the production function, it does not provide information on whether and to what extent public infrastructure can explain those shifts. The traditional Solow residual is actually a 'measure of our ignorance' of the productivity growth. One of the objectives of the present section is to identify the contribution of public infrastructure on the productivity growth using information from the parameter estimates derived from the dual cost function framework. 
More analytically, totally differentiating the dual cost function (1) with respect to time yields a measure of cost-side productivity growth measure

$$
-\varepsilon_{\mathrm{Ct}}=-\frac{\Delta C}{C}+\varepsilon_{\mathrm{CY}} \frac{\Delta Y}{Y}+\sum_{i} S_{i} \frac{\Delta P_{i}}{P_{i}}
$$

where $\mathrm{P}_{\mathrm{i}}$ are the prices of private purchased inputs $(\forall \mathrm{i}=\mathrm{L}, \mathrm{K}), \mathrm{S}_{\mathrm{i}}$ is the share of ith input in total cost, $\mathrm{Y}$ represents the industrial output, $\mathrm{C}$ is the total cost, $\Delta$ indicates the derivative with respect to time, while $\varepsilon_{C Y}$ is the partial derivative of the dual cost function with respect to output.

In Equation (8a) $-\varepsilon_{\mathrm{Ct}}$, is expected to be positive since total costs decline with technical change.

Ohta (1974) shows that the primal (production-side) productivity growth measure can be derived from the dual (cost-side) productivity expression by substituting the total derivative of costs with respect to time, $t$, into equation (8a). Moreover, the derivative of total cost with respect to time from equation $\mathrm{C}=\Sigma \mathrm{P}_{\mathrm{i}} \mathrm{X}_{\mathrm{i}}(\forall \mathrm{i}=\mathrm{L}, \mathrm{K})$ is $\mathrm{dC} / \mathrm{dt}=$ $\Sigma_{\mathrm{i}} \mathrm{P}_{\mathrm{i}} \mathrm{dX}_{\mathrm{i}} / \mathrm{dt}+\Sigma_{\mathrm{i}} \mathrm{X}_{\mathrm{i}} \mathrm{dP}_{\mathrm{i}} / \mathrm{dt}$ in the general form with $\mathrm{i}$ inputs of production. Substituting this expression into (8a) we get the link between the dual and the primal (productionside) productivity growth measure as follows

$$
-\varepsilon_{\mathrm{Ct}}=\varepsilon_{\mathrm{CY}} \frac{\Delta Y}{Y}-\sum_{i} \quad \mathrm{~S}_{\mathrm{i}} \frac{\Delta X_{i}}{X_{i}}
$$

The main novelty of the productivity measure in equation $(8 \mathrm{~b})$ is that it takes into account scale effects by including $\varepsilon_{\mathrm{CY}}$ rather than imposing the assumption that is often found in productivity growth studies (see Berndt (1990)) of constant returns to scale over all inputs of production. As equation (7) shows, in the case of constant returns to scale (CRS hereafter), $\varepsilon_{\mathrm{CY}}=1$, the productivity growth measure $(8 \mathrm{~b})$ reduces to the familiar primal-index number expression $\varepsilon_{\mathrm{Yt}}=(\Delta \mathrm{Y} / \mathrm{Y})-\Sigma_{\mathrm{i}} \mathrm{S}_{\mathrm{i}}\left(\Delta \mathrm{X}_{\mathrm{i}} / \mathrm{X}_{\mathrm{i}}\right)$. However, CRS is a rather restrictive assumption to apply for all the twenty Greek manufacturing industries. Hence, in the case of non-CRS, the productivity growth measure should be modified as proposed in Morrison and Schwartz (1996) in order to take into account the impact of public infrastructure, but also the contributions of technical change.

Modifying productivity growth measure for the case of non-CRS means that one has to estimate $\varepsilon_{\mathrm{CY}}$. In addition, if public infrastructure enters as an unpaid input in the dual cost function one requires to modify the productivity growth measure $(8 b)$ in order to identify the contribution of public infrastructure to the cost-output relationships.

Following Morrison and Schwartz (1994) a modification is given as follows

$$
-\varepsilon_{\mathrm{Ct}}=\varepsilon_{\mathrm{CY}} \frac{\Delta Y}{Y}-\sum_{i=L, K, M} S_{i} \frac{\Delta X_{i}}{X_{i}}-\mathrm{S}_{\mathrm{G}} \frac{\Delta G}{G}
$$


where $\mathrm{S}_{\mathrm{G}}$ is the 'shadow share' of public infrastructure, and $\mathrm{X}_{\mathrm{i}}$ are the private purchased inputs.

Equation (9) represents the corrected 'technical change' measure, which recognises individually the contribution of private purchased inputs and public infrastructure on productivity growth.

The estimation of $\varepsilon_{\mathrm{CY}}$ is feasible once the embodied cost changes are decomposed into scale economies and the effects of infrastructure. Morrison and Schwartz (1994) argue that $\varepsilon_{\mathrm{CY}}$ is given as

$$
\varepsilon_{\mathrm{CY}}=\frac{Y}{C} \frac{d C}{d Y}=\varepsilon^{\mathrm{L}}{ }_{\mathrm{CY}}-\varepsilon_{\mathrm{CG}} \varepsilon_{\mathrm{GY}}
$$

where $\varepsilon^{\mathrm{L}}{ }_{\mathrm{CY}}$ is the long-run elasticity of cost with respect to output ( $\left.\mathrm{d} \operatorname{lnC} / \mathrm{d} \ln \mathrm{Y}\right), \varepsilon_{\mathrm{CG}}$ is the cost elasticity with respect to public infrastructure ( $\mathrm{dlnC} / \mathrm{d} \ln G$ ), and $\varepsilon_{\mathrm{GY}}$ is the long-run elasticity of demand for public infrastructure with respect to output.

Moreover, equation (10) consists of the scale economies (first term on the far right hand side), and the effects of 'shadow share' of public infrastructure (first part of second term) times the elasticity of public infrastructure with respect to output. Furthermore, $\varepsilon^{\mathrm{L}}{ }_{\mathrm{CY}}$ is the inverse of the measure of long run returns to scale: (i) if $\varepsilon^{\mathrm{L}}{ }_{C Y}$ $=1$ then there are CRS, (ii) if $\varepsilon^{\mathrm{L}}{ }_{\mathrm{CY}}>1$ then there are decreasing returns to scale (DRS), (iii) if $\varepsilon^{\mathrm{L}} \mathrm{CY}<1$ then there are increasing returns to scale (IRS). The elasticity of total cost with respect to public infrastructure, $\varepsilon_{\mathrm{CG}}$, is equal to zero if public infrastructure does not have any effect on costs. The elasticity of public infrastructure with respect to output, $\varepsilon_{\mathrm{GY}}$, indicates 'the long-run implicit returns' to public infrastructure. Moreover, the sign and the magnitude of this parameter indicate whether public infrastructure is marginal cost reducing or marginal cost increasing. Thus, $\varepsilon_{\mathrm{CG}}, \varepsilon_{\mathrm{GY}}$ reflects the compound cost effect of a marginal change in public infrastructure.

In order to identify the contribution of public infrastructure on the productivity growth we combine equation (7) (the primal rate of productivity growth) with equation (9) as follows

$$
\varepsilon_{\mathrm{Yt}}=-\varepsilon_{\mathrm{Ct}}-\left(\varepsilon_{\mathrm{CY}}-1\right) \frac{\Delta Y_{i}}{Y}+\mathrm{S}_{\mathrm{G}} \frac{\Delta G_{i}}{G_{i}}
$$

Subsequently, substituting equation (10) into equation (11) gives a measure of productivity growth that decomposes the Solow residual into the impacts of technical change, scale economies, and the contribution of public infrastructure as follows

$$
\varepsilon_{\mathrm{Yt}}=-\varepsilon_{\mathrm{Ct}}-\left(\varepsilon_{\mathrm{CY}}^{\mathrm{L}}-1\right) \frac{\Delta Y}{Y}+\mathrm{S}_{\mathrm{G}} \frac{\Delta G}{G}-\mathrm{S}_{\mathrm{G}} \varepsilon_{\mathrm{GY}} \frac{\Delta Y}{Y}
$$




$$
=-\varepsilon_{\mathrm{Ct}}-\left(\varepsilon_{\mathrm{CY}}^{\mathrm{L}}-1\right) \frac{\Delta Y}{Y}+\mathrm{GDIR}+\mathrm{GIND}
$$

where GDIR $=\mathrm{S}_{\mathrm{G}} \frac{\Delta G}{G}$, and GIND $=-\mathrm{S}_{\mathrm{G}} \varepsilon_{\mathrm{GY}} \frac{\Delta Y}{Y}$.

Equation (12) is a flexible way to disentangle the impact of technical change, scale economies and the provision of public infrastructure on the productivity growth of industrial output. Additionally, the decomposition of public infrastructure's effects into the direct and indirect can be identified. Moreover, the sum of these two effects gives the total contribution of public infrastructure on productivity growth. This categorisation of the effects of public infrastructure (as proposed by Morrison and Schwartz (1996)) aims to show that the productivity growth does not only depend on the technological change, and the scale effects, but also equally on the relative growth rates of output and public infrastructure, as well as on the size of the 'shadow share', $\mathrm{S}_{\mathrm{G}}$, or alternatively defined on the productivity effect of public infrastructure.

Moreover, one can notice that most of the terms on the right hand side of equation (12) are given from the parameter estimates of the dual cost function where this is expressed in terms of the translog cost function as given in equation (1). Specifically, $\varepsilon_{\mathrm{Ct}}$ is the elasticity of cost with respect to time. ${ }^{4} \varepsilon_{\mathrm{GY}}$ is the elasticity of the demand of public infrastructure with respect to output and it is given from the parameter estimate of equation (1), $\gamma_{\mathrm{YG}} . \mathrm{S}_{\mathrm{G}}$ is the optimal demand for public infrastructure or the shadow share' of public infrastructure as given in equation ( $3 \mathrm{~b}$ ). Hence by estimating equation (1) one can use the parameter estimates and equation (3b) to estimate $S_{\mathrm{G}} \cdot \varepsilon^{\mathrm{L}} \mathrm{CY}_{\mathrm{C}}$ can be estimated from equation (10). The rest of the parameters in equation (12), $\Delta \mathrm{Y} / \mathrm{Y}$, $\Delta \mathrm{G} / \mathrm{G}$, can be directly computed from the data.

In particular, using this equation we are able to estimate the direct (GDIR) and indirect (GIND) impact of public infrastructure on the productivity growth of the Greek manufacturing industries. Moreover, the direct impact of public infrastructure identifies the contribution of the 'shadow share' of public infrastructure (or alternatively defined the 'social return' to public infrastructure) times the percentage growth rate of public infrastructure $(\Delta \mathrm{G} / \mathrm{G})$ on the productivity growth. The indirect impact of public infrastructure affects the productivity growth through the growth rate of output, the 'shadow share' of public infrastructure, and the elasticity of demand for public infrastructure with respect to output. The combined effect of these impacts measures the total impact of public infrastructure on the productivity growth (GTOT).

${ }^{4}$ More analytically, the elasticity of cost with respect to time is: $\frac{d \ln C}{d \ln T}=\alpha_{\mathrm{T}}+\gamma_{\mathrm{YT}} \ln \mathrm{Y}+\sum_{i=L, K} \gamma_{\Gamma l} \ln P_{i}$ $+\beta_{\mathrm{TT}} \mathrm{T}+\gamma_{\mathrm{TG}} \operatorname{lnG}$, and it can be computed using the parameter estimates of equation (1). Note that this elasticity is equal with the productivity growth in the case of constant returns to scale over all inputs of production. 


\section{DATA AND THE ESTIMATION PROCEDURE}

The data set of the present paper consists of two digit Greek industries based on the international standard classification of industry (SIC). Table 1 reports the different Greek manufacturing industries that compiles our data set.

Table 1 Classification of Greek Industrial Sectors

\begin{tabular}{l|c|c|c|}
\hline \hline SIC & INDUSTRY & SIC & INDUSTRY \\
\hline 20 & Food & 30 & Rubber and Plastic Products \\
21 & Beverages & 31 & Chemicals \\
22 & Tobacco & 32 & Petroleum \\
23 & Textiles & 33 & Non- Metallic Mineral Products \\
24 & Footwear and Wearing Apparel & 34 & Basic Metal Industry \\
25 & Wood and Cork & 35 & Metal Products \\
26 & Furniture & 36 & Machinery and Appliances \\
27 & Paper & 37 & Electrical Supplies \\
28 & Printing-Publishing & 38 & Transport Equipment \\
29 & Leather & 39 & Miscellaneous Manufacturing Industries \\
\hline \hline
\end{tabular}

Source: Annual Industrial Survey of Greece, National Statistical Office of Greece.

For the above manufacturing industries time series for value added have been collected from various issues of Annual Industrial Survey published by the National Statistical Office of Greece. Value added is preferred to gross output, since the total cost function contains labour and private capital stock as private purchased inputs of production. Although it would be useful to take into account the effects of intermediate inputs on the cost structure of the Greek industries, unfortunately there are not available data for this type of inputs. However in other similar studies value added had been extensively used as the exogenous level of output (see Lynde and Richmond (1993)).

The labour input is measured as number of employees in industrial units with more than twenty employees. In the Annual Industrial Survey those industries are mentioned as 'large scale manufacturing'. The price of labour is derived by dividing the total labour cost by the number of employees. Total labour cost is the sum of wages and salaries paid to employees. Time series for labour input are obtained from the Annual Industrial Survey. 
The time series of private capital stock includes equipment, structures, inventories and land. The depreciable assets of private capital stock like equipment and structures are estimated using the perpetual inventory method. ${ }^{5}$ The stock of capital equals to a weighted sum of all past investment. The efficiency of an asset is assumed to decline monotonically with age and it is approximated by a rectangular hyperbola. The underlying assumption is that the flow of the derived services from capital stock affect the cost structure of Greek manufacturing industries. These services are assumed to be a constant proportion of private capital stock. The price of private capital stock is measured as $P_{K}=\alpha_{K}(r+\delta) T$, where $\alpha_{K}$ is the asset price or investment deflator, $r$ is the rate of return or opportunity cost of investment, $\delta$ is the depreciation rate, and $\mathrm{T}$ measures the corporate tax rate of industries. The series of private capital stock and its price are obtained from the Greek Annual Industrial Survey, the Ministry of National Economy, and the Centre of Planning and Economic Performance (KEПE).

The time series concerning public capital stock is defined as core infrastructure following Diewert (1986). More analytically core infrastructure embodies a big portion of services derived from public capital stock in ports, railways, motor vehicles, civil aviation, roads, electrical, and communication facilities. Notice that in the way we define infrastructure we deliberately exclude the capital stock that is directly used in the production of public goods. Public infrastructure is considered to be a not marketable good, since there is no market price charged for its services. Hence in the present analysis public infrastructure is treated as an unpaid input of production along the line of previous research (see Nadiri and Mamouneas (1992), Morrisson and Swartz (1994), Lynde and Richmond (1993)). The time series of net public capital stock are obtained from the Centre of Planning and Economic Research (KEПЕ), and the Ministry of National Economy.

All the above mentioned time series are expressed in constant terms with base year 1985.

Having discussed the data set of our analysis we turn now our attention to the estimation procedure that is followed in the next sections. The system of equations that we estimate consists of the total cost function and the labour demand. Our choice of the estimation method is the seemingly unrelated regression (SUR). The choice of the specific method is based on the fact that employs more information from a system of equations. Thus it is more efficient than single equation OLS. However the seemingly unrelated regression is sensitive to which cost share equation is excluded from the sum of the cost share equations (recall that the sum of the cost shares of private purchased inputs equals to one, and thus because of the emerged singularity only $n-1$ cost share equations can be estimated). To overcome this problem we apply the iterated seemingly unrelated regression method (ISUR), which ensures that the parameter estimates of the system approximately approach those obtained by using maximum likelihood method, and thus they are invariant to the choice of the excluded cost share equation (see Judge (1980)). The overall efficiency of the seemingly

\footnotetext{
${ }^{5}$ Skoutzos and Matheos (1993) give further explanations of the way that capital stock series were derived for the Greek industrial sectors.
} 
unrelated regression is further enhanced by imposing optimisation behaviour among industries, linear homogeneity, and symmetry.

\section{EMPIRICAL ESTIMATIONS}

\subsection{PARAMETER ESTIMATES OF THE TRANSLOG COST FUNCTION}

The translog cost function has to satisfy the monotonicity and concavity conditions locally in our sample period, 1959-1990, in order to be well behaved. More precisely, the translog cost function should be according to the theory monotonically nondecreasing and concave in the prices of private purchased inputs, which are labour and private capital stock, non-decreasing in output and non-increasing and convex in public capital stock and the index of technology. In the next paragraphs we discuss each of these conditions as we proceed with the interpretation of our estimations. ${ }^{6}$

Table 2 reports the parameter estimates of the translog cost function, as they have been estimated using iterated seemingly unrelated regression method. Monotonicity implies that total cost function should be increasing in the prices of labour and private capital stock. Thus the average value shares of private capital stock and labour, $\alpha_{K}$ and $\alpha_{\mathrm{L}}$, should be positive. Table 2 shows that across all the twenty Greek manufacturing industries $\alpha_{\mathrm{K}}$ and $\alpha_{\mathrm{L}}$ are positive and statistical significant, enforcing the monotonicity condition.

According to the underlying theory the total cost function has to be non-increasing in public infrastructure, which is treated as a quasi fixed factor. Effectively this suggests that an increase in public infrastructure should reduce the total cost. Hence the parameter estimate of the average value share of public infrastructure, $\alpha_{\mathrm{G}}$, should be negative. In fact the average value share estimates of $\alpha_{G}$ is negative and statistical significant for most of the manufacturing industries. Therefore, an increase in the level of public infrastructure will reduce the total cost of the Greek industries. However in some industrial sectors a significant positive value for $\alpha_{G}$ is observed. These industries are $22,23,24$, and $31 .^{7}$ Overall it appears that public infrastructure by

\footnotetext{
${ }^{6}$ Concavity in inputs' prices is ensured when the matrix of substitution elasticities of private purchased inputs $(\mathrm{L}, \mathrm{K})$ is negative semidefinite, which means that the main diagonal of this matrix should consists of negative values. The diagonal contains the own substitution elasticities of private purchased inputs which have to be negative throughout the sample period (1959-1990). Therefore in order to test for concavity we have to estimate the Allen mean substitution elasticities for the private purchased inputs. Table 1 in Appendix 1 reports these elasticities. The own substitution elasticities, $\sigma_{\mathrm{LL}}$ and $\sigma_{\mathrm{KK}}$, are negative for all the industrial sectors. Hence the law of demand is not violated, since the demands for private capital stock and labour seem to be price responsive, suggesting that changes in inputs prices lead to changes in their demands towards the opposite direction. The reported cross substitution elasticity, $\sigma_{\mathrm{KL}}$, is positive as it is required by our theoretical model. Therefore, private capital stock and labour are substitutes in the production procedure.
}

\footnotetext{
${ }^{7}$ Although these parameter estimates may suggest violation of the underlying theory, the fitted share of public capital stock is negative for all the industries during the sample period, rejecting this violation (results are available on request).
} 
reducing total cost has a positive productive effect on the Greek industrial production at a disaggregated level.

The coefficients $\alpha_{T}$ and $\alpha_{Y}$ represent the average of the negative rate of the technical change and the average share of output, $\alpha_{Y}$, in the total cost respectively. The total cost function has to be non-increasing in $\mathrm{T}$, the rate of technical change. As it is observed in Table 2 the parameter estimates of $\alpha_{T}$ are negative and statistical significant for most of the industries. On the other hand the average share of output is reported positive in most of the cases. In the industries that $\alpha_{T}$ and $\alpha_{Y}$ do not carry the expected from the underlying theory sing they are reported to be statistical insignificant.

The parameter, $\beta_{\mathrm{LL}}, \beta_{\mathrm{KK}}$, and $\gamma_{\mathrm{KL}}$ are the second order partial derivatives of the total cost function with respect to private purchased inputs. In the literature these parameters are mentioned as the 'constant share elasticities' and provide indications of the patterns of substitution of the relative participation of the private purchased inputs cost shares in the total cost. A positive 'constant share elasticity' suggests that the value share of ith input gets comparatively larger as the ith input's quantity increases $(\forall \mathrm{i}=\mathrm{L}, \mathrm{K})$. On the other hand negative constant share elasticity suggests that the value share of ith input decreases as the ith input quantity increases $(\forall i=L, K)$. Notice that in our theoretical specification only private capital stock and labour enter the total cost function, public capital stock is taken as an unpaid, quasi fixed input of production. Therefore, private capital stock and labour can not be complements in the production procedure. In the unlikely case that they are complements, it will be implausibly implied that industries are able to increase infinitely their output by employing private purchased inputs without any cost. However our parameter estimates indicate that the coefficient $\gamma_{\mathrm{KL}}$ is negative and statistical significant for all the industrial sectors. Only in the case of industry 39 is positive but nevertheless statistically insignificant.

The parameters $\gamma_{\mathrm{LG}}$ and $\gamma_{\mathrm{KG}}$ captures the spill-over effect of public infrastructure on private purchased inputs. These parameters measure the bias effect of public infrastructure on the cost share of labour and private capital stock. A negative value for $\gamma_{\mathrm{LG}}$ and $\gamma_{\mathrm{KG}}$ indicates the cost share of ith private purchased input $(\forall \mathrm{i}=\mathrm{L}, \mathrm{K})$ declines as public infrastructure increases. Table 2 shows that for the majority of the industrial sectors there is a positive and statistical significant bias effect stemming out of public infrastructure towards private capital stock, while the opposite result is true for the case of labour.

The scale biases effects are given by the parameter estimates of $\gamma_{K Y}$ and $\gamma_{L Y}$. These coefficients can be viewed as the private purchased inputs' share elasticities with respect to output. These parameters show the change of private purchased inputs' shares in total cost after a change in the level of output. Notice that the basic condition for estimating those coefficients is that the translog cost function is not homothetic, and thus the cross product parameters with respect to output are different than zero. As much as the interpretation of those coefficients is concerned a positive number would imply that the specific input is normal, meaning that the ith input share in total cost would go up as output increases. On the other hand a negative parameter estimate 
would indicate an inferior input. Our estimations show that private capital stock decreases with an increase of output in the industries $20,23,24,30,33,35$, while in the rest of the industries it seems that it is a normal good. The opposite is true for the labour's share in total cost.

The coefficient $\beta_{Y Y}$ represents the cost flexibility. In the industries $21,22,23,25,26$, 31,36 and 37 the marginal cost decreases as output expands.

The parameter $\gamma_{\mathrm{YG}}$ is interpreted by Feltenstein and Ha (1995) as the response of marginal cost to changes in public infrastructure. This parameter estimate can indicate whether public infrastructure is marginal cost reducing or marginal cost increasing. For most of the industries 21, 22, 23, 24, 27, 28, 31, 33, 34, 35, 36, 37 and 38, public infrastructure reduces significantly marginal cost. In the rest industries $\gamma_{\mathrm{YG}}$ carries a positive sign, but only in the industries 20 and 31 the parameter estimates are statistical significant different from zero. 
Table 2 Parameter Estimates of the Translog Cost Function

\begin{tabular}{|c|c|c|c|c|c|c|c|c|c|c|c|c|c|c|c|c|c|c|c|c|}
\hline & $\alpha_{\mathrm{K}}$ & $\alpha_{\mathrm{L}}$ & $\alpha_{\mathrm{G}}$ & $\alpha_{Y}$ & $\alpha_{\mathrm{T}}$ & $\beta_{\mathrm{LL}}$ & $\beta_{\mathrm{KK}}$ & $\beta_{Y Y}$ & $\beta_{\mathrm{TT}}$ & $\beta_{\mathrm{GG}}$ & $\gamma_{\mathrm{KL}}$ & $\gamma_{\mathrm{LG}}$ & $\gamma_{\mathrm{KG}}$ & $\gamma_{\mathrm{YK}}$ & $\gamma_{\mathrm{YG}}$ & $\gamma_{\mathrm{YL}}$ & $\gamma_{\mathrm{TY}}$ & $\gamma_{\mathrm{TL}}$ & $\gamma_{\mathrm{TK}}$ & $\gamma_{\mathrm{TG}}$ \\
\hline 20 & $\begin{array}{l}0.42 \\
(6.79)\end{array}$ & $\begin{array}{l}0.58 \\
(9.36)\end{array}$ & $\begin{array}{l}-0.99 \\
(-1.86) \\
\end{array}$ & $\begin{array}{l}4.58 \\
3.92\end{array}$ & $\begin{array}{l}-0.46 \\
(-4.46) \\
\end{array}$ & $\begin{array}{l}0.036 \\
(2.06)\end{array}$ & $\begin{array}{l}0.03 \\
(2.0)\end{array}$ & $\begin{array}{l}1.09 \\
(1.2))\end{array}$ & $\begin{array}{l}0.022 \\
(1.62) \\
\end{array}$ & $\begin{array}{l}1.18 \\
(2.87) \\
\end{array}$ & $\begin{array}{r}-0.036 \\
(-2.06) \\
\end{array}$ & $\begin{array}{l}-0.12 \\
(-2.08)\end{array}$ & $\begin{array}{l}0.12 \\
(2.08) \\
\end{array}$ & $\begin{array}{l}-0.01 \\
(-0.08) \\
\end{array}$ & $\begin{array}{l}0.6 \\
(4.56)\end{array}$ & $\begin{array}{l}0.01 \\
(0.08)\end{array}$ & $\begin{array}{l}-0.13 \\
(-2.4)\end{array}$ & $\begin{array}{l}-0.21 \\
(-3.9) \\
\end{array}$ & $\begin{array}{l}0.21 \\
(3.9)\end{array}$ & $\begin{array}{l}0.092 \\
(4.23)\end{array}$ \\
\hline 21 & $\begin{array}{l}0.53 \\
(4.27)\end{array}$ & $\begin{array}{l}0.47 \\
(5.72)\end{array}$ & $\begin{array}{l}-0.94 \\
(-2.17)\end{array}$ & $\begin{array}{l}3.48 \\
(4.04)\end{array}$ & $\begin{array}{l}-0.32 \\
(-3.11)\end{array}$ & $\begin{array}{l}0.04 \\
(2.8)\end{array}$ & $\begin{array}{l}0.04 \\
(2.8)\end{array}$ & $\begin{array}{l}-8.97 \\
(-2.31)\end{array}$ & $\begin{array}{l}0.009 \\
(0.9)\end{array}$ & $\begin{array}{l}0.71 \\
(0.94)\end{array}$ & $\begin{array}{l}-0.04 \\
(-2.8)\end{array}$ & $\begin{array}{l}-0.05 \\
(-0.6)\end{array}$ & $\begin{array}{l}0.05 \\
(0.6)\end{array}$ & $\begin{array}{l}0.05 \\
(2.38)\end{array}$ & $\begin{array}{l}0.23 \\
(0.43)\end{array}$ & $\begin{array}{l}-0.05 \\
(-2.38)\end{array}$ & $\begin{array}{l}-0.09 \\
(-2.57)\end{array}$ & $\begin{array}{l}-0.03 \\
(-7.0)\end{array}$ & $\begin{array}{l}0.03 \\
(7.0)\end{array}$ & $\begin{array}{l}0.11 \\
(4.0)\end{array}$ \\
\hline 22 & $\begin{array}{l}0.24 \\
(1.16)\end{array}$ & $\begin{array}{l}0.76 \\
(7.0)\end{array}$ & $\begin{array}{l}1.02 \\
(3.23)\end{array}$ & $\begin{array}{l}0.58 \\
(1.62)\end{array}$ & $\begin{array}{l}.03 \\
(0.27)\end{array}$ & $\begin{array}{l}.08 \\
(3.1)\end{array}$ & $\begin{array}{l}0.08 \\
(3.1)\end{array}$ & $\begin{array}{l}-0.01 \\
(-0.08)\end{array}$ & $\begin{array}{l}-0.003 \\
(-0.59)\end{array}$ & $\begin{array}{l}0.50 \\
(0.18)\end{array}$ & $\begin{array}{l}-0.08 \\
(-3.1)\end{array}$ & $\begin{array}{l}0.13 \\
(0.46)\end{array}$ & $\begin{array}{l}-0.13 \\
(-0.46)\end{array}$ & $\begin{array}{l}0.04 \\
(2.2)\end{array}$ & $\begin{array}{l}-0.054 \\
(-0.20)\end{array}$ & $\begin{array}{l}-0.04 \\
(-2.2)\end{array}$ & $\begin{array}{l}0.02 \\
(1.22)\end{array}$ & $\begin{array}{l}-0.01 \\
(-3.0)\end{array}$ & $\begin{array}{l}0.01 \\
(3.0)\end{array}$ & $\begin{array}{l}-0.02 \\
(-0.8)\end{array}$ \\
\hline 23 & $\begin{array}{l}0.29 \\
(2.27) \\
\end{array}$ & $\begin{array}{l}0.71 \\
(7.5) \\
\end{array}$ & $\begin{array}{l}1.51 \\
(2.34) \\
\end{array}$ & $\begin{array}{l}-0.21 \\
(-0.17) \\
\end{array}$ & $\begin{array}{l}-0.07 \\
(-0.84) \\
\end{array}$ & $\begin{array}{l}0.03 \\
(1.2) \\
\end{array}$ & $\begin{array}{l}0.03 \\
(1.2)\end{array}$ & $\begin{array}{l}-2.83 \\
(-1.48) \\
\end{array}$ & $\begin{array}{l}-0.01 \\
(-1.14) \\
\end{array}$ & $\begin{array}{l}1.14 \\
(1.33) \\
\end{array}$ & $\begin{array}{l}-0.03 \\
(-1.2) \\
\end{array}$ & $\begin{array}{l}-0.15 \\
(-2.61) \\
\end{array}$ & $\begin{array}{l}0.15 \\
(2.61) \\
\end{array}$ & $\begin{array}{l}-0.05 \\
(-1.56) \\
\end{array}$ & $\begin{array}{l}-0.697 \\
(-1.07) \\
\end{array}$ & $\begin{array}{l}0.05 \\
(1.56)\end{array}$ & $\begin{array}{l}0.06 \\
(1.19) \\
\end{array}$ & $\begin{array}{l}-0.02 \\
(-4.0) \\
\end{array}$ & $\begin{array}{l}0.02 \\
(4.0) \\
\end{array}$ & $\begin{array}{l}0.009 \\
(0.42)\end{array}$ \\
\hline 24 & $\begin{array}{l}0.18 \\
(1.67) \\
\end{array}$ & $\begin{array}{l}0.82 \\
(9.37) \\
\end{array}$ & \begin{tabular}{|l}
0.54 \\
$(4.45)$ \\
\end{tabular} & $\begin{array}{l}1.02 \\
(2.42) \\
\end{array}$ & $\begin{array}{l}-0.15 \\
(-1.58) \\
\end{array}$ & $\begin{array}{l}0.1 \\
(7.0) \\
\end{array}$ & $\begin{array}{l}0.1 \\
(7.0) \\
\end{array}$ & $\begin{array}{l}0.09 \\
(0.14) \\
\end{array}$ & $\begin{array}{l}-0.01 \\
(-1.21) \\
\end{array}$ & $\begin{array}{l}1.15 \\
(2.40) \\
\end{array}$ & $\begin{array}{l}-0.1 \\
(-7.0) \\
\end{array}$ & $\begin{array}{l}0.006 \\
(0.12) \\
\end{array}$ & $\begin{array}{l}-0.006 \\
(-0.12) \\
\end{array}$ & $\begin{array}{l}-0.01 \\
(-0.5) \\
\end{array}$ & $\begin{array}{l}-0.21 \\
(-1.39) \\
\end{array}$ & $\begin{array}{l}0.01 \\
(0.57) \\
\end{array}$ & $\begin{array}{l}0.01 \\
(0.64) \\
\end{array}$ & $\begin{array}{l}-0.01 \\
(-2.6) \\
\end{array}$ & $\begin{array}{l}0.01 \\
(2.6) \\
\end{array}$ & $\begin{array}{l}0.04 \\
(2.330 \\
\end{array}$ \\
\hline 25 & $\begin{array}{l}0.87 \\
(3.55)\end{array}$ & $\begin{array}{l}0.13 \\
(0.94)\end{array}$ & $\begin{array}{l}0.78 \\
(1.9)\end{array}$ & $\begin{array}{l}-0.21 \\
(-0.24)\end{array}$ & 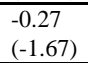 & $\begin{array}{l}0.03 \\
(1.98)\end{array}$ & $\begin{array}{l}0.03 \\
(1.98)\end{array}$ & $\begin{array}{l}-2.7 \\
(-2.610\end{array}$ & $\begin{array}{l}-0.02 \\
(-3.36)\end{array}$ & $\begin{array}{l}2.67 \\
(4.97)\end{array}$ & $\begin{array}{l}-0.036 \\
(-1.9)\end{array}$ & $\begin{array}{l}-0.11 \\
(-1.12)\end{array}$ & $\begin{array}{l}0.11 \\
(1.12)\end{array}$ & $\begin{array}{l}0.13 \\
(3.26)\end{array}$ & $\begin{array}{l}-1.77 \\
(-2.81)\end{array}$ & $\begin{array}{l}-0.13 \\
(-3.26) \\
\end{array}$ & $\begin{array}{l}0.06 \\
(1.97)\end{array}$ & $\begin{array}{l}-0.03 \\
(-5.59) \\
\end{array}$ & $\begin{array}{l}.03 \\
(5.59)\end{array}$ & $\begin{array}{l}0.1 \\
(2.82)\end{array}$ \\
\hline 26 & $\begin{array}{l}0.59 \\
(3.85) \\
\end{array}$ & $\begin{array}{l}0.41 \\
(3.31) \\
\end{array}$ & $\begin{array}{l}-0.16 \\
(-0.37) \\
\end{array}$ & $\begin{array}{l}2.40 \\
(2.20) \\
\end{array}$ & $\begin{array}{l}0.04 \\
(0.52) \\
\end{array}$ & $\begin{array}{l}0.03 \\
(1.3) \\
\end{array}$ & $\begin{array}{l}0.03 \\
(1.3)\end{array}$ & $\begin{array}{l}-0.27 \\
(-0.38) \\
\end{array}$ & $\begin{array}{l}0.004 \\
(0.4) \\
\end{array}$ & $\begin{array}{l}2.35 \\
(3.94) \\
\end{array}$ & $\begin{array}{l}-0.03 \\
(-1.3) \\
\end{array}$ & $\begin{array}{l}0.09 \\
(1.04) \\
\end{array}$ & $\begin{array}{l}-0.09 \\
(-1.04) \\
\end{array}$ & $\begin{array}{l}0.03 \\
(1.2) \\
\end{array}$ & $\begin{array}{l}-1.09 \\
(-2.64) \\
\end{array}$ & $\begin{array}{l}-0.03 \\
(-1.2) \\
\end{array}$ & $\begin{array}{l}-0.04 \\
(-0.90 \\
\end{array}$ & $\begin{array}{l}-0.02 \\
(-3.23) \\
\end{array}$ & $\begin{array}{l}0.02 \\
(3.23) \\
\end{array}$ & $\begin{array}{l}-0.04 \\
(-0.41) \\
\end{array}$ \\
\hline 27 & $\begin{array}{l}0.62 \\
(3.40)\end{array}$ & $\begin{array}{l}0.38 \\
(3.81)\end{array}$ & $\begin{array}{l}1.0 \\
(-1.46)\end{array}$ & $\begin{array}{l}3.84 \\
(3.24)\end{array}$ & $\begin{array}{l}-0.06 \\
(2.07)\end{array}$ & $\begin{array}{l}0.06 \\
(3.1)\end{array}$ & $\begin{array}{l}0.06 \\
(3.1)\end{array}$ & $\begin{array}{l}4.71 \\
(1.24)\end{array}$ & $\begin{array}{l}0.02 \\
(2.07)\end{array}$ & $\begin{array}{l}-1.6 \\
(-1.58)\end{array}$ & $\begin{array}{l}-0.06 \\
(-3.1)\end{array}$ & $\begin{array}{l}-0.24 \\
(-1.63)\end{array}$ & $\begin{array}{l}0.24 \\
(1.63)\end{array}$ & $\begin{array}{l}0.07 \\
(2.38)\end{array}$ & $\begin{array}{l}-0.37 \\
(-0.44)\end{array}$ & $\begin{array}{l}-0.07 \\
(-2.38)\end{array}$ & $\begin{array}{l}-0.12 \\
(-2.28)\end{array}$ & $\begin{array}{l}-0.03 \\
(-7.2)\end{array}$ & $\begin{array}{l}0.03 \\
(7.2)\end{array}$ & $\begin{array}{l}0.03 \\
(1.4)\end{array}$ \\
\hline 28 & $\begin{array}{l}0.37 \\
(2.22)\end{array}$ & $\begin{array}{l}0.63 \\
(5.1)\end{array}$ & $\begin{array}{l}-0.17 \\
(-0.23) \\
\end{array}$ & $\begin{array}{l}2.16 \\
(1.64)\end{array}$ & $\begin{array}{l}.18 \\
(2.0)\end{array}$ & $\begin{array}{l}0.07 \\
(2.86)\end{array}$ & $\begin{array}{l}0.07 \\
(2.86)\end{array}$ & $\begin{array}{l}3.94 \\
(1.82)\end{array}$ & $\begin{array}{l}0.0003 \\
(0.04)\end{array}$ & $\begin{array}{l}1.37 \\
(1.3)\end{array}$ & $\begin{array}{l}-0.07 \\
(-2.8)\end{array}$ & $\begin{array}{l}0.19 \\
(0.96)\end{array}$ & $\begin{array}{l}-0.19 \\
(-0.96)\end{array}$ & $\begin{array}{l}0.04 \\
(1.28)\end{array}$ & $\begin{array}{l}-0.93 \\
(-1.51)\end{array}$ & $\begin{array}{l}-0.04 \\
(-1.28) \\
\end{array}$ & $\begin{array}{l}-0.02 \\
(-0.44)\end{array}$ & $\begin{array}{l}-0.01 \\
(-2.36)\end{array}$ & $\begin{array}{l}0.01 \\
(2.36)\end{array}$ & $\begin{array}{l}-0.02 \\
(-1.23) \\
\end{array}$ \\
\hline 29 & $\begin{array}{l}0.37 \\
(3.42) \\
\end{array}$ & $\begin{array}{l}0.63 \\
(8.58) \\
\end{array}$ & $\begin{array}{l}-0.43 \\
(-0.97) \\
\end{array}$ & $\begin{array}{l}2.85 \\
(3.32) \\
\end{array}$ & $\begin{array}{l}0.05 \\
(0.61) \\
\end{array}$ & $\begin{array}{l}0.05 \\
(2.61) \\
\end{array}$ & $\begin{array}{l}0.05 \\
(2.61) \\
\end{array}$ & $\begin{array}{l}0.99 \\
(0.93)\end{array}$ & $\begin{array}{l}0.009 \\
(1.12) \\
\end{array}$ & $\begin{array}{l}-0.43 \\
(-0.34) \\
\end{array}$ & $\begin{array}{l}-0.05 \\
(-2.6) \\
\end{array}$ & $\begin{array}{l}.007 \\
(-0.08) \\
\end{array}$ & $\begin{array}{l}0.007 \\
(0.08)\end{array}$ & $\begin{array}{l}0.02 \\
(1.19) \\
\end{array}$ & $\begin{array}{l}0.33 \\
(0.87) \\
\end{array}$ & $\begin{array}{l}-0.02 \\
(-1.19) \\
\end{array}$ & $\begin{array}{l}-0.04 \\
(-1.31) \\
\end{array}$ & $\begin{array}{l}-0.02 \\
(-4.5) \\
\end{array}$ & $\begin{array}{l}0.02 \\
(4.59) \\
\end{array}$ & $\begin{array}{l}-0.01 \\
(-0.77) \\
\end{array}$ \\
\hline 30 & $\begin{array}{l}0.46 \\
(0.77)\end{array}$ & $\begin{array}{l}0.54 \\
(1.26)\end{array}$ & $\begin{array}{l}1.1 \\
(1.27) \\
\end{array}$ & $\begin{array}{l}-0.15 \\
(-0.08) \\
\end{array}$ & $\begin{array}{l}0.11 \\
(0.32) \\
\end{array}$ & $\begin{array}{l}-0.12 \\
(-4.2) \\
\end{array}$ & $\begin{array}{l}-0.12 \\
(-4.2)\end{array}$ & $\begin{array}{l}2.30 \\
(0.37) \\
\end{array}$ & $\begin{array}{l}-0.01 \\
(-1.15) \\
\end{array}$ & $\begin{array}{l}0.17 \\
(0.15) \\
\end{array}$ & $\begin{array}{l}0.12 \\
(4.2)\end{array}$ & $\begin{array}{l}-0.22 \\
(-1.31)\end{array}$ & $\begin{array}{l}0.22 \\
(1.31) \\
\end{array}$ & $\begin{array}{l}-0.14 \\
(-0.98) \\
\end{array}$ & $\begin{array}{l}-1.81 \\
(-2.14) \\
\end{array}$ & $\begin{array}{l}0.14 \\
(0.98) \\
\end{array}$ & $\begin{array}{l}0.05 \\
(0.82) \\
\end{array}$ & $\begin{array}{l}-0.03 \\
(-1.8) \\
\end{array}$ & $\begin{array}{l}0.03 \\
(1.88) \\
\end{array}$ & $\begin{array}{l}-0.01 \\
(-0.03) \\
\end{array}$ \\
\hline 31 & $\begin{array}{l}0.41 \\
(2.01)\end{array}$ & $\begin{array}{l}0.59 \\
(6.39)\end{array}$ & $\begin{array}{l}0.62 \\
(7.01)\end{array}$ & $\begin{array}{l}-1.22 \\
(-1.37)\end{array}$ & $\begin{array}{l}0.08 \\
(5.65)\end{array}$ & $\begin{array}{l}0.08 \\
(5.65)\end{array}$ & $\begin{array}{l}0.08 \\
(5.65)\end{array}$ & $\begin{array}{l}3.79 \\
(-3.68)\end{array}$ & $\begin{array}{l}-0.001 \\
(-0.21)\end{array}$ & $\begin{array}{l}0.34 \\
(0.26)\end{array}$ & $\begin{array}{l}-0.08 \\
(-5.6)\end{array}$ & $\begin{array}{l}-0.16 \\
(-1.28)\end{array}$ & $\begin{array}{l}0.16 \\
(1.28)\end{array}$ & $\begin{array}{l}0.02 \\
(1.04)\end{array}$ & $\begin{array}{l}.53 \\
(3.71)\end{array}$ & $\begin{array}{l}-0.02 \\
(-1.04)\end{array}$ & $\begin{array}{l}0.07 \\
(3.87)\end{array}$ & $\begin{array}{l}-0.02 \\
(-3.2) \\
\end{array}$ & $\begin{array}{l}0.02 \\
(3.27)\end{array}$ & 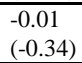 \\
\hline 32 & $\begin{array}{l}0.51 \\
(4.77)\end{array}$ & $\begin{array}{l}.49 \\
(7.25)\end{array}$ & $\begin{array}{l}-1.11 \\
(-6.37)\end{array}$ & $\begin{array}{l}5.04 \\
(6.74)\end{array}$ & $\begin{array}{l}.074 \\
(0.44)\end{array}$ & $\begin{array}{l}-0.004 \\
(-0.2)\end{array}$ & $\begin{array}{l}-0.004 \\
(-0.2)\end{array}$ & $\begin{array}{l}3.05 \\
(2.98)\end{array}$ & $\begin{array}{l}0.002 \\
(0.25)\end{array}$ & $\begin{array}{l}0.58 \\
(0.52)\end{array}$ & $\begin{array}{l}-0.04 \\
(-0.2)\end{array}$ & $\begin{array}{l}0.07 \\
(0.38)\end{array}$ & $\begin{array}{l}-0.07 \\
(-0.38)\end{array}$ & $\begin{array}{l}0.12 \\
(3.78)\end{array}$ & $\begin{array}{l}-1.86 \\
(-3.68)\end{array}$ & 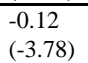 & $\begin{array}{l}-0.16 \\
(-4.87)\end{array}$ & $\begin{array}{l}-0.04 \\
(-7.8)\end{array}$ & $\begin{array}{l}0.04 \\
(7.8)\end{array}$ & $\begin{array}{l}-0.13 \\
(3.36)\end{array}$ \\
\hline 33 & $\begin{array}{l}0.26 \\
(1.08)\end{array}$ & $\begin{array}{l}0.84 \\
(12.8)\end{array}$ & $\begin{array}{l}-0.8 \\
(-1.46)\end{array}$ & $\begin{array}{l}0.56 \\
(0.48)\end{array}$ & $\begin{array}{l}-0.23 \\
(-2.05)\end{array}$ & $\begin{array}{l}0.05 \\
(4.3)\end{array}$ & $\begin{array}{l}0.05 \\
(4.3)\end{array}$ & $\begin{array}{l}1.84 \\
(0.49)\end{array}$ & $\begin{array}{l}-0.01 \\
(-1.31)\end{array}$ & $\begin{array}{l}-0.64 \\
(-0.48)\end{array}$ & $\begin{array}{l}-0.05 \\
(-4.3)\end{array}$ & $\begin{array}{l}-0.16 \\
(-2.12)\end{array}$ & $\begin{array}{l}0.16 \\
(2.12)\end{array}$ & $\begin{array}{l}-0.06 \\
(-2.98)\end{array}$ & $\begin{array}{l}0.6 \\
(0.86)\end{array}$ & $\begin{array}{l}0.06 \\
(2.98)\end{array}$ & $\begin{array}{l}0.04 \\
(0.82)\end{array}$ & $\begin{array}{l}-0.06 \\
(-1 . .9)\end{array}$ & $\begin{array}{l}0.06 \\
(1.9)\end{array}$ & $\begin{array}{l}-0.05 \\
(2.28)\end{array}$ \\
\hline 34 & $\begin{array}{l}0.77 \\
(4.43)\end{array}$ & $\begin{array}{l}0.23 \\
(3.26)\end{array}$ & $\begin{array}{l}-0.27 \\
(-0.89) \\
\end{array}$ & $\begin{array}{l}1.03 \\
(0.89)\end{array}$ & $\begin{array}{l}0.22 \\
(0.91)\end{array}$ & $\begin{array}{l}0.04 \\
(2.2)\end{array}$ & $\begin{array}{l}0.04 \\
(2.2)\end{array}$ & $\begin{array}{l}2.6 \\
(2.39)\end{array}$ & $\begin{array}{l}0.001 \\
(0.16)\end{array}$ & $\begin{array}{l}0.9 \\
(1.09)\end{array}$ & $\begin{array}{l}-0.04 \\
(-2.2)\end{array}$ & $\begin{array}{l}0.07 \\
(0.49)\end{array}$ & $\begin{array}{l}-0.07 \\
(-0.49)\end{array}$ & $\begin{array}{l}0.28 \\
(4.24)\end{array}$ & $\begin{array}{l}0.64 \\
(1.11)\end{array}$ & $\begin{array}{l}-0.28 \\
(-4.24) \\
\end{array}$ & $\begin{array}{l}-0.01 \\
(-0.25)\end{array}$ & $\begin{array}{l}-0.05 \\
(-5.0) \\
\end{array}$ & $\begin{array}{l}.05 \\
(5.0)\end{array}$ & $\begin{array}{l}-0.02 \\
(-0.42) \\
\end{array}$ \\
\hline 35 & $\begin{array}{l}0.21 \\
(1.63) \\
\end{array}$ & $\begin{array}{l}0.79 \\
(7.58) \\
\end{array}$ & $\begin{array}{l}-0.27 \\
(-0.64) \\
\end{array}$ & $\begin{array}{l}3.09 \\
(3.27) \\
\end{array}$ & $\begin{array}{l}-0.21 \\
(-1.68) \\
\end{array}$ & $\begin{array}{l}0.08 \\
(3.98) \\
\end{array}$ & $\begin{array}{l}0.08 \\
(3.98) \\
\end{array}$ & $\begin{array}{l}2.71 \\
(2.64) \\
\end{array}$ & $\begin{array}{l}0.01 \\
(1.65) \\
\end{array}$ & $\begin{array}{l}-0.05 \\
(-0.09) \\
\end{array}$ & $\begin{array}{l}-0.08 \\
(-3.9) \\
\end{array}$ & $\begin{array}{l}-0.06 \\
(-1.04) \\
\end{array}$ & $\begin{array}{l}0.06 \\
(1.04) \\
\end{array}$ & $\begin{array}{l}-0.02 \\
(-0.69) \\
\end{array}$ & $\begin{array}{l}-0.56 \\
(-1.29) \\
\end{array}$ & $\begin{array}{l}0.02 \\
(0.69)\end{array}$ & $\begin{array}{l}-0.07 \\
(-1.92) \\
\end{array}$ & $\begin{array}{l}-0.01 \\
(-1.7) \\
\end{array}$ & $\begin{array}{l}0.01 \\
(1.74) \\
\end{array}$ & $\begin{array}{l}0.03 \\
(1.26)\end{array}$ \\
\hline 36 & $\begin{array}{l}0.63 \\
(5.45)\end{array}$ & $\begin{array}{l}0.37 \\
(3.97)\end{array}$ & $\begin{array}{l}-0.21 \\
(-0.47)\end{array}$ & $\begin{array}{l}2.56 \\
(2.91)\end{array}$ & $\begin{array}{l}-0.24 \\
(-1.9)\end{array}$ & $\begin{array}{l}.05 \\
(2.4)\end{array}$ & $\begin{array}{l}0.05 \\
(2.4)\end{array}$ & $\begin{array}{l}-1.7 \\
(-1.55)\end{array}$ & $\begin{array}{l}0.006 \\
(0.88)\end{array}$ & $\begin{array}{l}.22 \\
(4.72)\end{array}$ & $\begin{array}{l}-0.05 \\
(-2.4)\end{array}$ & $\begin{array}{c}-0.002 \\
(-0.05)\end{array}$ & $\begin{array}{l}0.002 \\
(0.05)\end{array}$ & $\begin{array}{l}0.08 \\
(3.16)\end{array}$ & $\begin{array}{l}-1.99 \\
(-4.43)\end{array}$ & $\begin{array}{l}-0.08 \\
(-3.16)\end{array}$ & $\begin{array}{l}-0.05 \\
(-1.5)\end{array}$ & $\begin{array}{l}-0.02 \\
(-5.0)\end{array}$ & $\begin{array}{l}0.02 \\
(5.06)\end{array}$ & $\begin{array}{l}-0.05 \\
(-2.07)\end{array}$ \\
\hline 37 & $\begin{array}{l}0.54 \\
(3.02) \\
\end{array}$ & $\begin{array}{l}0.46 \\
(5.66)\end{array}$ & $\begin{array}{l}-0.3 \\
(-0.47) \\
(\end{array}$ & $\begin{array}{l}1.47 \\
(1.17) \\
\end{array}$ & $\begin{array}{l}0.08 \\
(0.41)\end{array}$ & $\begin{array}{l}0.05 \\
(2.23) \\
\end{array}$ & $\begin{array}{l}0.05 \\
(2.23) \\
\end{array}$ & $\begin{array}{l}5.95 \\
(-0.69)\end{array}$ & $\begin{array}{l}-0.017 \\
(-1.32) \\
\end{array}$ & $\begin{array}{l}1.8 \\
(1.00\end{array}$ & $\begin{array}{l}-0.05 \\
(-2.2) \\
\end{array}$ & $\begin{array}{l}0.19 \\
(1.76) \\
\end{array}$ & $\begin{array}{l}-0.19 \\
(-1.76)\end{array}$ & $\begin{array}{l}0.21 \\
(3.24) \\
\end{array}$ & $\begin{array}{l}-1.91 \\
(-2.4) \\
\end{array}$ & $\begin{array}{l}-0.21 \\
(-3.24) \\
\end{array}$ & $\begin{array}{l}0.005 \\
(0.08)\end{array}$ & $\begin{array}{l}-0.04 \\
(-4.9) \\
\end{array}$ & $\begin{array}{l}0.04 \\
(4.94)\end{array}$ & $\begin{array}{l}-0.03 \\
(-0.84) \\
\end{array}$ \\
\hline 38 & $\begin{array}{l}0.32 \\
(1.24)\end{array}$ & $\begin{array}{l}0.68 \\
(2.2)\end{array}$ & $\begin{array}{l}-1.03 \\
(-0.9)\end{array}$ & $\begin{array}{l}9.15 \\
(3.66)\end{array}$ & 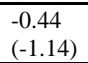 & $\begin{array}{l}0.11 \\
(5.36)\end{array}$ & $\begin{array}{l}0.11 \\
(5.36)\end{array}$ & $\begin{array}{l}4.13 \\
(3.8)\end{array}$ & $\begin{array}{l}0.076 \\
(3.88) \\
\end{array}$ & $\begin{array}{l}-8.18 \\
(-7.76)\end{array}$ & $\begin{array}{l}-0.11 \\
(-5.3)\end{array}$ & $\begin{array}{l}-0.26 \\
(-2.04)\end{array}$ & $\begin{array}{l}0.26 \\
(2.04) \\
\end{array}$ & $\begin{array}{l}0.08 \\
(1.28)\end{array}$ & $\begin{array}{l}-0.46 \\
(-0.59)\end{array}$ & $\begin{array}{l}-0.08 \\
(-1.28)\end{array}$ & $\begin{array}{l}-0.27 \\
(-3.41)\end{array}$ & $\begin{array}{l}-0.01 \\
(-0.9)\end{array}$ & $\begin{array}{l}0.01 \\
(0.94)\end{array}$ & $\begin{array}{l}-0.08 \\
(-1.12) \\
\end{array}$ \\
\hline 39 & $\begin{array}{l}0.79 \\
(4.6)\end{array}$ & $\begin{array}{l}0.21 \\
(1.79)\end{array}$ & $\begin{array}{l}-0.56 \\
(-1.33)\end{array}$ & $\begin{array}{l}0.39 \\
(0.51)\end{array}$ & 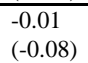 & $\begin{array}{l}-0.005 \\
(-0.3)\end{array}$ & $\begin{array}{l}-0.005 \\
(-0.3)\end{array}$ & $\begin{array}{l}4.35 \\
(2.88)\end{array}$ & $\begin{array}{l}-0.01 \\
(-2.83)\end{array}$ & $\begin{array}{l}-0.07 \\
(-0.11)\end{array}$ & $\begin{array}{l}0.05 \\
(0.3)\end{array}$ & $\begin{array}{l}0.12 \\
(1.16)\end{array}$ & $\begin{array}{l}-0.12 \\
(-1.16)\end{array}$ & $\begin{array}{l}0.08 \\
(2.66)\end{array}$ & $\begin{array}{l}-0.16 \\
(-0.34) \\
(\end{array}$ & $\begin{array}{l}-0.08 \\
(-2.66)\end{array}$ & $\begin{array}{l}0.03 \\
(1.38)\end{array}$ & $\begin{array}{l}-0.03 \\
(-5.5)\end{array}$ & $\begin{array}{l}.03 \\
(5.5)\end{array}$ & $\begin{array}{l}-0.03 \\
(0.7)\end{array}$ \\
\hline
\end{tabular}

Source: Author's Estimations. 
The technical change biases are expressed by the parameters $\gamma_{\mathrm{KT}}, \gamma_{\mathrm{LT}}$ and $\gamma_{\mathrm{GT}}$. More analytically these parameters represent the change of ith input's share in total cost over time. A positive number means that the usage of ith input $(\forall \mathrm{i}=\mathrm{L}, \mathrm{K}$, and $\mathrm{G}$ ) increases with time. The opposite is true for a negative parameter estimate. Table 2 reports that in most of the industries the labour's share in the total cost decreases with time, indicating that technical change lead to decreases in the required inputs of production. . The opposite is true for capital stock. Moreover, it is plausible to expect that labour savings occur over time, mainly because of advanced technological innovations in the production procedure. However it is hard to accept that the same outcome applies to public capital stock. Even though the deterioration of public investment in infrastructure projects over time seem to confirm our present parameter estimates (see also Katseli and Mamatzakis (1994)).

The parameter estimate of $\gamma_{\mathrm{YT}}$ explains how technical change affects the growth of output. In most of the industrial sectors the growth of output decreases over time, supporting previous evidence of a prolonged slow down of the Greek industrial growth of output (see Mamatzakis (1999)).

The parameter estimate of $\beta_{\mathrm{TT}}$ indicates the rate of technical acceleration. A positive number implies that technical change increases over time, while the opposite is true for a negative number.

\subsection{COSTS, PRODUCTIVITY GROWTH, AND PUBLIC SECTOR CAPITAL}

A way to clarify the effects of public infrastructure on total cost is to estimate the elasticity of cost with respect to public capital stock. The sign and the magnitude of cost elasticity with respect to public infrastructure, $\eta_{\mathrm{G}}$, will indicate whether public infrastructure is a cost-reducing or cost-increasing input of production. More precisely, the sign and the magnitude $\eta_{\mathrm{G}}$ provides us with information concerning the 'productivity effect'.

Table (3) reports the parameter estimates of $\eta_{G}$ for all the Greek manufacturing industries. The presented estimations are the means of the estimates of the average impact of core public infrastructure on each of the industries during the sample period, 1959-1990. Clearly, the effect of public infrastructure on total cost is negative for all the industrial sectors (apart from industry 29), implying that increases in public infrastructure reduce total costs. Therefore investment in public capital stock has a positive productivity effect on the Greek industries by shifting downwards their cost functions.

Notice that public capital stock saves costs even for the industrial sectors, 22, 23, 24 and 31 , for which a cost-increasing effect of public capital stock on their costs has been reported in Table 2 (see coefficient $\beta_{\mathrm{G}}$ ). 
Table 3 Elasticity of Cost with Respect to Public Infrastructure

\begin{tabular}{|l|ccc|}
\hline \multicolumn{1}{|l|}{$S I C$} & $\eta_{G}$ & SIC & $\eta_{G}$ \\
\hline \hline 20 & -0.028 & 30 & -0.65 \\
21 & -0.10 & 31 & -0.56 \\
22 & -0.47 & 32 & -0.42 \\
23 & -0.66 & 33 & -0.59 \\
24 & -0.72 & 34 & -0.56 \\
25 & -0.78 & 35 & -0.42 \\
26 & -0.43 & 36 & -0.65 \\
27 & -0.53 & 37 & -0.64 \\
28 & -0.65 & 38 & -0.22 \\
29 & 0.54 & 39 & -0.68 \\
\hline
\end{tabular}

Source: Author's Estimations.

In conclusion, the provided evidence favours the beneficial effect of public infrastructure on the productivity of Greek industries. Previous research on the area is in line with our findings. Nadiri and Mamouneas (1991) for US economy, Feltenstein and Ha (1995) for Mexican economy, and Conrad and Seitz (1994) for German economy show that public infrastructure exhibits indeed positive productivity effects.

\subsection{PRODUCTIVITY GROWTH}

To estimate the productivity growth of the twenty two-digit Greek manufacturing industries we employ the productivity measure as given by equation (12). The advantage of equation (12) is that allows the decomposition of productivity growth into the technological change, scale effects, and direct (GDIR $\left.=\mathrm{S}_{\mathrm{G}} \frac{\Delta G}{G}\right)$ and indirect (GIND $\left.=-\mathrm{S}_{\mathrm{G}} \varepsilon_{\mathrm{GY}} \frac{\Delta Y}{Y}\right)$ effects of public infrastructure. The magnitude of those direct and indirect effects of public infrastructure depend on the growth rate of public capital stock, $\frac{\Delta G}{G}$, the growth rate of industrial output, $\frac{\Delta Y}{Y}$, the value of the 'shadow share' of public infrastructure, $S_{\mathrm{G}}$, and the elasticity of the share of public capital stock with respect to output, $\varepsilon_{\mathrm{GY}}$. Notice that the direct contribution of public infrastructure on productivity growth may be small, even in the case that a high $S_{G}$ is reported, if $G$ is small relative to $\mathrm{G}$.

Moreover, we use the parameter estimates of the dual translog cost function to measure productivity growth (or alternatively defined total factor productivity), as 
given in equation (12), of the twenty Greek manufacturing industries. Table 4 reports the productivity growth for these manufacturing industries. On average the productivity growth of all the Greek manufacturing industries was 2.5 percent during the period 1959-1990, albeit industries 21 (beverages), 22 (tobacco), 28 (printing and publishing), 31 (chemicals), and 34 (basic metal) exhibited a negative productivity growth.

In the literature there are only few attempts to measure productivity growth at a twodigit level of Greek manufacturing industries. To our knowledge only Kintis (1978), and Korres (1995) provide some information concerning productivity growth, using parametric methodology. Korres (1995) reports that on average the total factor productivity of the Greek manufacturing industries was approximately 4.5 percent in the 1962-1987. This estimate seems to overestimate total factor productivity compared with our estimates mainly due to the exclusion of scale and public infrastructure effects. In particular, the empirical evidence of the present research argues that infrastructure investment can potentially explain part of the Greek productivity growth. Hence, the effect of infrastructure should be given important consideration and not neglected when examining the productivity growth of the Greek manufacturing industries.

Table 4 Average Productivity Growth of the Greek Manufacturing Industries

\begin{tabular}{|cccc|}
\hline & Productivity Growth & & Productivity Growth \\
20 & 7.7 & 30 & 6.67 \\
21 & -2.1 & 31 & -9.9 \\
22 & -8.4 & 32 & 2.3 \\
23 & 6.6 & 33 & 3.6 \\
24 & 6.3 & 34 & -7.0 \\
25 & 1.8 & 35 & 6.2 \\
26 & 3.7 & 36 & 8.7 \\
27 & 1.9 & 37 & 4.2 \\
28 & -0.5 & 38 & 7.1 \\
29 & 4.4 & 39 & 7.4 \\
\hline
\end{tabular}

Source: Author's Estimations

Moreover, because public infrastructure exhibits scale effects, as it has been indicated by the parameter estimate of $\varepsilon_{\mathrm{GY}}$, its contribution to industrial productivity growth does not depend only on its own growth, it also depends on the augmented growth rate of industrial output for each individual industry, $\varepsilon_{\mathrm{GY}} \frac{\Delta Y}{Y}$. Thus, although the reported parameter estimates of the 'shadow share' of public infrastructure, $\mathrm{S}_{\mathrm{G}}$, indicate a costsaving impact on most of the twenty two-digit Greek manufacturing industries, the combined effect of GDIR and GIND, GTOT, must be positive so that public infrastructure contributes partly to the observed productivity growth of the Greek manufacturing industries.

Table 5 presents the direct, GDIR, and indirect, GIND, effects of public infrastructure as well as their sum, GTOT. These measures can be interpreted as the percentage 
impact of public infrastructure on the productivity growth rate of twenty two-digit Greek manufacturing industries. The mean value of GDIR for almost all the two-digit manufacturing industries $(20,22,23,24,25,26,27,28,30,32,33,34,35,36,37,38$, and 39) is positive, suggesting that public infrastructure enhance their productivity growth. Moreover, the direct impact of public infrastructure (GDIR) on the productivity growth ranges from 0.01 percent in the manufacturing industries 23 (textiles) to 0.039 percent in the industries 24 (footwear). The remaining industries 21 (beverages), and 29 (leather) hold a negative GDIR, which indicates a negative contribution of public infrastructure on productivity growth. Although the magnitude of those estimates (with a range between -0.0007 percent to -0.002 percent) is very low, it suggests that the slow down in the growth rate of public infrastructure is responsible for this negative impact on productivity growth for the manufacturing industry (29) and (21).

Table 5 Parameter Estimates of the Productivity Growth

\begin{tabular}{|l|ccc|}
\hline SIC & GDIR & GIND & GTOT \\
\hline \hline 20 & 0.040 & -0.039 & 0.001 \\
21 & -0.0007 & -0.0005 & -0.001 \\
22 & 0.022 & 0.0041 & 0.026 \\
23 & 0.011 & 0.023 & 0.035 \\
24 & 0.039 & 0.031 & 0.07 \\
25 & 0.03 & 0.23 & 0.26 \\
26 & 0.014 & 0.038 & 0.53 \\
27 & 0.027 & 0.035 & 0.062 \\
28 & 0.032 & 0.1 & 0.13 \\
29 & -0.002 & -0.006 & -0.009 \\
30 & 0.034 & 0.22 & 0.26 \\
31 & 0.029 & -0.077 & -0.048 \\
32 & 0.017 & 0.14 & 0.16 \\
33 & 0.029 & -0.061 & -0.031 \\
34 & 0.029 & -0.064 & -0.034 \\
35 & 0.010 & 0.022 & 0.033 \\
36 & 0.033 & 0.21 & 0.24 \\
37 & 0.032 & 0.21 & 0.24 \\
38 & 0.002 & 0.01 & 0.01 \\
39 & 0.035 & 0.017 & 0.053 \\
\hline
\end{tabular}

Source: Author's Estimations.

As far as the total impact of public infrastructure on the productivity growth is concerned, in the case that the GTOT carries a positive sign, part of the reported productivity growth should be contributed to public infrastructure, rather than only to technological change. This is mainly due the fact that $\varepsilon_{\mathrm{GY}} \frac{\Delta Y}{Y}$ is growing more slowly than the growth rate of public infrastructure. Morrison and Schwartz (1996) argues that in that case infrastructure investment more than keeps pace with output expansion and therefore has an impact in addition to the required input increase to support output growth'. The total impact of public infrastructure on the productivity 
growth, GTOT, is positive for the industries $20,22,23,24,25,26,27,28,30,32,35$, $36,37,38$ and 39 .

However, the mean of GTOT over the period 1960-1990 is reported negative for the rest of the industries $(21,29,31,33$, and 34). Hence, one may argue the low level of public infrastructure depresses the productivity growth of those manufacturing industries. Moreover, this negative impact varies from -0.001 percent for the industry (21) (beverages) to -0.048 percent for the industry (31) (chemicals). ${ }^{8}$ These negative total impacts (GTOT) imply that the low level of public infrastructure is partly responsible for the reported low productivity growth of these Greek-manufacturing industries. Specifically, the negative sign of GTOT suggests that the slow down of industrial productivity growth is partly due to a shortfall of public infrastructure investment. That is to say the growth rate of public infrastructure does not keep pace with the augmented growth rate of output, $\varepsilon_{\mathrm{GY}} \frac{\Delta Y}{Y}$.

Table 6 presents the direct, indirect, and total impact of public infrastructure on productivity growth over time. These findings indicate that the total contribution (GTOT) of public infrastructure to the productivity growth has been reduced over time for most of the two-digit Greek manufacturing industries, apart from 30 (rubber), 32 (petroleum) and 38 (transport), because of a lower growth rate of public infrastructure. In addition, for most of these industries, apart from 38 (transport equipment), GTOT is reported positive in the sixties, while it declines sharply in the late seventies and eighties. Specifically, Table 6 reveals that a shortfall in public infrastructure depressed the overall productivity growth of the Greek manufacturing industries especially in the eighties. This decline of the productivity growth due to shortfall in public infrastructure varies from a factor -0.001 percent in industry 21 (beverages) to -0.17 percent in industry 31 (chemicals). Undoubtedly, these findings suggest that the Greek manufacturing industries can benefit from investing in public infrastructure. Alas, in the late seventies and eighties a curtailment of public investment expenditures in favour of public consumption expenditures combat the industrialisation of the country.

\footnotetext{
${ }^{8}$ Notice that Chemical manufacturing industry (31) exhibits a very high negative productivity growth (see Table 4).
} 
Table 6 Direct, Indirect, and Total Effect of Public Infrastructure on Productivity Growth over Time

\begin{tabular}{|ccccc|ccc|ccc|}
\hline & \multicolumn{3}{c}{$1960-1970$} & \multicolumn{3}{c}{$1970-1980$} & \multicolumn{3}{c|}{$1980-1990$} \\
& GDIR & GIND & GTOT & GDIR & GIND & GTOT & GDIR & GIND & GTOT \\
\hline \hline 20 & 0.12 & 0.27 & 0.39 & 0.042 & 0.087 & 0.13 & -0.036 & -0.044 & -0.08 \\
21 & -0.005 & 0.002 & -0.002 & -0.0003 & -0.001 & -0.0004 & 0.002 & -0.003 & -0.001 \\
22 & 0.020 & 0.0004 & 0.02 & 0.03 & 0.004 & 0.034 & 0.018 & 0.0067 & 0.024 \\
23 & 0.021 & 0.033 & 0.055 & 0.012 & 0.034 & 0.046 & 0.002 & 0.007 & 0.01 \\
24 & 0.049 & 0.017 & 0.067 & 0.045 & 0.048 & 0.093 & 0.023 & 0.027 & 0.051 \\
25 & 0.05 & 0.17 & 0.22 & 0.036 & 0.37 & 0.41 & 0.009 & 0.14 & 0.15 \\
26 & 0.036 & 0.11 & 0.15 & 0.013 & 0.048 & 0.061 & -0.003 & -0.04 & -0.04 \\
27 & 0.031 & 0.016 & 0.047 & 0.032 & 0.038 & 0.071 & 0.018 & 0.05 & 0.06 \\
28 & 0.035 & 0.043 & 0.078 & 0.04 & 0.13 & 0.17 & 0.023 & 0.13 & 0.16 \\
29 & 0.021 & 0.001 & 0.003 & -0.003 & -0.011 & -0.015 & -0.006 & -0.009 & -0.016 \\
30 & 0.042 & 0.18 & 0.22 & 0.038 & 0.025 & 0.29 & 0.022 & 0.22 & 0.22 \\
31 & 0.031 & 0.15 & 0.18 & 0.035 & -0.17 & -0.13 & 0.02 & -0.19 & -0.17 \\
32 & 0.0035 & 0.025 & 0.028 & 0.027 & 0.15 & 0.17 & 0.019 & 0.26 & 0.28 \\
33 & 0.032 & -0.032 & $0.8 \times 10^{-4}$ & 0.036 & -0.081 & -0.045 & 0.021 & -0.071 & -0.049 \\
34 & 0.039 & -0.068 & -0.028 & 0.031 & -0.058 & -0.026 & 0.02 & -0.072 & -0.052 \\
35 & 0.026 & -0.059 & -0.033 & 0.01 & -0.025 & -0.015 & -0.0009 & 0.002 & 0.0011 \\
36 & 0.037 & 0.11 & 0.15 & 0.041 & 0.28 & 0.32 & 0.022 & 0.2 & 0.23 \\
37 & 0.036 & 0.15 & 0.18 & 0.039 & 0.25 & 0.29 & 0.021 & 0.25 & 0.27 \\
38 & -0.002 & -0.015 & -0.037 & 0.087 & 0.021 & 0.030 & 0.018 & 0.032 & 0.057 \\
39 & 0.041 & 0.005 & 0.046 & 0.042 & 0.030 & 0.073 & 0.023 & 0.018 & 0.042 \\
\hline
\end{tabular}

Source: Author's Estimations.

Moreover, our findings in this paper verify that the slow down in public investment results to a sluggish productivity growth for most of the manufacturing industries, hypothecating their prosperity. Moreover, the above findings suggest that most of the Greek manufacturing industries have suffered from shortages in the provision of public infrastructure in the late seventies and eighties, which has resulted to a lower productivity growth.

\section{CONCLUSION}

In the present paper we use the dual translog cost function in order to investigate the effects of public infrastructure on the cost structure and productivity performance of twenty two-digit Greek manufacturing industries. Public infrastructure enters the production procedure and thus the dual cost function as an unpaid input of production. It is therefore expected that industries would benefit from the services derived from public infrastructure.

The main results of our empirical analysis show that public infrastructure exhibits a significant productive effect, though it varies across industries. The cost elasticity with respect to public infrastructure is reported negative for the majority of two-digit manufacturing industries, implying that the cost function shifts downward as public 
investment in infrastructure projects increases. Input demands are also affected by changes in public infrastructure. Public capital stock is found to be complement to private capital stock, suggesting that the former crowds-in the latter, while there is a substitution relationship between public infrastructure and labour. These factors' bias effects seem to hold for most the Greek manufacturing industries.

Additionally, we find that public infrastructure contributes to productivity growth, and thus it is at least a partially responsible for the observed slowdown in productivity growth of the Greek manufacturing industries. In particular, the total impact of infrastructure on the productivity growth is positive for most of the industries in the sixties and seventies. Alas, although public infrastructure is found to enhance costsavings associated with technical change, in the eighties its contribution on the productivity growth mitigated, and for many industries has been actually reported negative. The curtailment of public investment in the late seventies and eighties can be held responsible for this development.

Thus, reductions in public infrastructure investment can have a detrimental effect on the productivity growth. Had public infrastructure attracted the appropriate attention of economic policy makers in Greece during the late seventies and the eighties the Greek manufacturing industries would have been much more productive.

The importance of the present empirical findings rests on the underlying economic policy implications. Based on the findings of this paper one can argue that reduction of public investment may be decisive for the slow down of the industrial sector of the Greek economy. In specific, the present study comes to fill the gap in the empirical literature by providing evidence of the positive contribution of public infrastructure on the development of the Greek industrial sector. Furthermore, these findings provide empirical evidence of what has been suggested by economists in Greece to be a detrimental factor for the development of the Greek industry (see Giannitsis (1988)), namely the decisive role of infrastructure in facilitating and supporting productive activities of the private sector.

The nationalisation of many ailing industries in the seventies and the eighties, and the general protectionistic attitude of the government have not been supportive for the development of the Greek industry. This policy has actually caused distortions that negatively affect the restructure of the sector into more competitive forms. An obvious alternative economic policy would have been to invest in infrastructure projects that seem to enhance the industrial productivity growth. 
Appendix

Table 1 Allen Substitution Elasticities and Economies of Scale

\begin{tabular}{|l|lllc|}
\hline SIC & $\sigma_{\mathrm{LL}}$ & $\sigma_{\mathrm{KK}}$ & $\sigma_{\mathrm{LK}}$ & $\begin{array}{c}\text { Economies of Scale } \\
\left(1 / \mathrm{E}_{\mathrm{CY}}\right)\end{array}$ \\
\hline \hline 20 & -0.82 & -0.88 & 0.85 & 0.71 \\
21 & -0.937 & -0.7 & 0.81 & 0.84 \\
22 & -0.66 & -0.61 & 0.64 & 0.96 \\
23 & -0.87 & -0.86 & 0.87 & 1.15 \\
24 & -0.38 & -0.79 & 0.55 & 1.00 \\
25 & -0.69 & -1.05 & 0.85 & 2.01 \\
26 & -0.75 & -1.02 & 0.87 & 1.01 \\
27 & -1.08 & -0.46 & 0.71 & 0.85 \\
28 & -0.7 & -0.65 & 0.68 & 0.757 \\
29 & -0.61 & -1.02 & 0.79 & 0.88 \\
30 & -1.65 & -1.36 & 1.49 & 1.08 \\
31 & -0.8 & -0.5 & 0.63 & 4.24 \\
32 & -1.37 & -0.75 & 1.01 & 2.97 \\
33 & -0.73 & -0.85 & 0.79 & 6.47 \\
34 & -0.93 & -0.69 & 0.81 & 1.19 \\
35 & -0.56 & -0.73 & 0.64 & 0.87 \\
36 & -0.68 & -0.92 & 0.79 & 0.97 \\
37 & -0.91 & -0.69 & 0.79 & 0.79 \\
38 & -1.03 & -0.06 & 0.25 & 0.58 \\
39 & -0.891 & -1.17 & 1.02 & 1.23 \\
\hline
\end{tabular}

Source: Author's Estimations.

\section{Bibliography}

Arrow, K.J. and M. Kurz (1970), "Public Investment, the Rate of Return, and Optimal Fiscal Policy," The John Hopkins Press, Baltimore.

Aschauer, D.A. (1989a) "Is Public Expenditure Productive?," Journal of Monetary Economics, 23, 177-200.

Aschauer, D.A. (1989b) "Does Public Capital Crowd Out Private Capital," Journal of Monetary Economics, 24, 177-200.

Aschauer, D.A. (1993) "Public Capital, Productivity, and Economic Growth," Working Paper, Sweden, Jonkoping.

Barro, R. (1990) “Government Spending in a Simple Model of Endogenous Growth,” Journal of Political Economy, 98.

Berndt E. R. (1991) "The Practise of Econometrics".

Berndt E. R. and Hansson B. (1992) "Measuring the Contribution of Public Infrastructure Capital in Sweden," Scand. J. of Economics, Supplement, 151-168.

Conrad K. and H. Seitz (1994) "The Economic Banefits of Public Infrastructure," Applied Economics, 26, 303-311.

Costa da Silva, J., R. Ellson and R. Martin (1987) "Public Capital, Regional Output and Development: Some Empirical Evidence,” Journal of Regional Science, 27.

Courakis, A. Fatima, M.-R, and Tridimas, G. (1993) "Public Expenditure Growth in Greece and Portugal: Wagner's Law and Beyond," 25, 125-134. 
Deno, K. (1988) "The Effect of Public Capital on US Manufacturing Activity: 1970 to 1978," Southern Economic Journal, 55.

Feltenstein A. and J. Ha (1995) "The Role of Infrastructure in Mexican Economic Reform," The World Bank Economic Review, Vol. 9, NO. 2, 287-304.

Ford, R. and P.Poret, (1991) "Infrastructure and the Private Sector Productivity," OECD Working Paper, No 91.

Hansen, (1965) "Unbalanced Growth and Regional Development," Western Economic Journal.

Hulten, C.R. and R.M. Schwab (1991) "Public Capital Formation and the Growth of Regional Manufacturing Industries," National Tax Journal, 44, No 4.

Inder, B. (1993) "Estimating Long-Run Relationships in Economics: A Comparison of Different Approaches," Journal of Econometrics, 57, 53-68.

Kaskarelis, I.A. (1997) "Aggregate Returns to Scale in Greek Manufacturing," Applied Economics, 29, 1673-78.

Katseli, L. T. and E.C. Mamatzakis (1994) "De-industrialisation Process in Selected Greek Regions,", University of Athens.

Kydland, F.E. and E.C. Prescott (1982), "Time to Build and Aggregate Fluctuations," Econometrica, 50, 1345-70.

Lunde C. and J. Richmont (1992) "The Role of Public Capital in Production," The Review of Economics and Statistics.

Lunde C. and J. Richmont (1993) "Public Capital and Long-Run Costs in U.K. Manufacturing," The Economic Journal, July, 103, 880-893.

Nadiri M. I. and T. P. Mamouneas (1994) "The Effects of Public Infrastructure and R\&D Capital on the Cost Structure and Performance of U.S. Manufacturing Industries," The Review of Economics and Statistics.

Mamatzakis, E.C. (1999), “Testing for Long Run Relationship Between Infrastructure and Private Capital Productivity: a Time Series Analysis for the Greek industry," Applied Economics Letters, April.

Mamatzakis, E.C. (1998), "Dynamic Responses of Private Sector Productivity to Public Infrastructure", QMW Discussion Paper, No 391, July.

Morrison, J. C. and A. E. Schwartz (1996) "State Infrastructure and Productive Performance," The American Economic Review, Dec..

Morrison, J. C. (1988) "Quasi-Fixed Inputs in U.S. and Japanese Manufacturing: a Generalized Leontief Restricted Cost Function approach," The Review of Economics and Statistics.

Munnel, A. H. (1990a) "Why Has Productivity Growth Declined? Productivity and Public Investment," Federal Reserve Bank of Boston, New England Economic Review, Jan-Feb, 3-22.

Munnel, A.H. (1990b) "How Does Public Infrastructure Affects Regional Economic Performance?," Federal Reserve Bank of Boston, New England Economic Review, Sep./Oct.

Munnel, A.H. (1992) "Infrastructure Investment and Economic Growth," The Journal of Economic Perspectives, 6, No 4.

Ratner, J.B. (1983), "Government Capital and the Production Function for US Private Output," Economics Letters, 13, 213-217.

Skoutzos, G. and Matheos (1993) "Net Capital Stock Formation for the Greek Economy," КЕПЕ. 